\title{
Distribution and sources of suspended particulate matter in the Kara Sea
}

\author{
MARINA KRAVCHISHINA, ALLA LEIN, VLADIMIR BURENKOV, \\ VLADIMIR ARTEM'EV \& ALEXANDER NOVIGATSKY \\ P.P. Shirshov Institute of Oceanology of the Russian Academy of Sciences \\ kravchishina@ocean.ru
}

\begin{abstract}
The distribution of suspended particulate matter (SPM) concentration in the Kara Sea was analysed based on ship and satellite data during the lowest ice cover periods in the Arctic (2007 and 2011). The distance of the river runoff with terrigenous SPM was recognized up to at least $76-76.5^{\circ} \mathrm{N}$ on the basis of isotope data and SPM concentrations and composition. The complex studies of SPM in the water column and in the benthic boundary layer provided new information about the supply and transformation of particles in the marine ecosystem.
\end{abstract}

Key words suspended particulate matter; recent sedimentation; organic carbon; remote sensing; biogeochemistry; Arctic

\section{INTRODUCTION}

The main features of suspended particulate matter (SPM) in marine waters are formed as a result of the mineral particles inflow and vital activity of marine organisms. The research of SPM of diverse origins with characteristic grain size from $0.5 \mu \mathrm{m}$ to $1 \mathrm{~mm}$ is of interest to different branches of oceanology, especially when studying biogeochemical processes.

The aim of this work is to study the regularities of the distribution and genetic composition of the SPM in the Kara Sea during the lowest ice cover in the Arctic using both satellite and field observations, as well as microbiological and isotope methods. Special attention is given to the study of cross-shelf transport of terrigenous SPM arriving with runoff from the Ob' and Yenisei rivers, since these rivers account for about $90 \%$ of the annual freshwater flow into the sea.

The research was carried out during the 57th and 59th cruises of RV Akademik Mstislav Keldysh in September-October 2007 and 2011, respectively. Climatic conditions over this part of the Arctic during those years were relatively similar (Flint 2010, Platonov et al. 2012). Ice cover was completely absent in the Kara Sea in the first part of the autumn. The largest reduction of the Arctic ice cover was in September 2007, compared with continuous observations from the end of the 1970s (Platonov et al. 2012).

\section{STUDY AREA}

The Kara Sea is a shallow shelf sea that is strongly influenced by the discharge of two of the largest Arctic rivers - the Ob' and the Yenisei rivers. They contribute about 50\% of the total river runoff discharged to the entire Eurasian Arctic. The modern discharge of SPM by the Ob' and Yenisei rivers is $15.5 \times 10^{6} \mathrm{t} \mathrm{year}^{-1}$ and $4.7 \times 10^{6} \mathrm{t} \mathrm{year}^{-1}$, respectively, at the gauging sites Igarka and Salekhard (Stein 2000). About 80\% of SPM is delivered in summer (Stein and Fahl 2004). Most of SPM (80-90\%) is trapped in the marginal filter where freshwater and salt-water mix (Lisitzyn 1995). Coastal erosion may be an important source of SPM input to the Kara Sea (Vasiliev et al. 2005).

In the high latitudes, the seasonal development of phytoplankton is mostly limited by the seasonality in photosynthetically available radiation (PAR) quantity, as well as riverine nutrient discharge and sea-ice cover. The maximum growth rate of phytoplankton can be observed in August and September; plankton blooms mainly consist of diatoms and cyanobacteria (Nöthig et al. 2003). The Kara Sea is an oligotrophic basin according to the primary production value (Vinogradov et al. 1994); i.e. it is characterized by a low phytoplankton biomass.

Studies on SPM concentration and isotopic composition of particulate organic carbon (POC) in the Kara Sea were previously carried out by Lukashin et al. (1999), Lisitzin et al. (2000), Gebhardt (2004), Kodina (2002), Galimov et al. (2006), Nagel et al. (2009), Ivanov et al. (2010), 
and others. They showed a strong terrestrial influence on SPM, which decreases in a northern direction.

\section{MATERIALS AND METHODS}

The water samples were collected using Niskin bottles mounted on a Rosette sampler. The water samples and fluffy layer from the benthic boundary layer (BBL) were collected using a Multiple Corer (KUM, company). In total, we collected $\sim 250$ samples along transects across the shelf (Fig. 1). The SPM mass concentration was determined by the standard technique of vacuum filtering at $400 \mathrm{mbar}$ using membrane filters (diameter $47 \mathrm{~mm}$, pore diameter $0.45 \mu \mathrm{m}$ ) (Cutter et al. 2010). The Multisizer 3 modification of a Coulter counter was used for the study of SPM grain size $(2-60 \mu \mathrm{m})$ (Benson et al. 2004). The SPM samples collected using vacuum filtration at $200 \mathrm{mbar}$ via GF/F fibreglass filters were analysed to obtain the content and isotope composition $\left(\delta^{13} \mathrm{C}\right)$ of organic carbon $\left(\mathrm{C}_{\text {org }}\right)$. The total number of bacterioplankton (TNB) in the samples was calculated (data courtesy of E.F. Veslopolova, INMI RAS). Methods are described in Ivanov et al. (2010) and Lein et al. (2011).

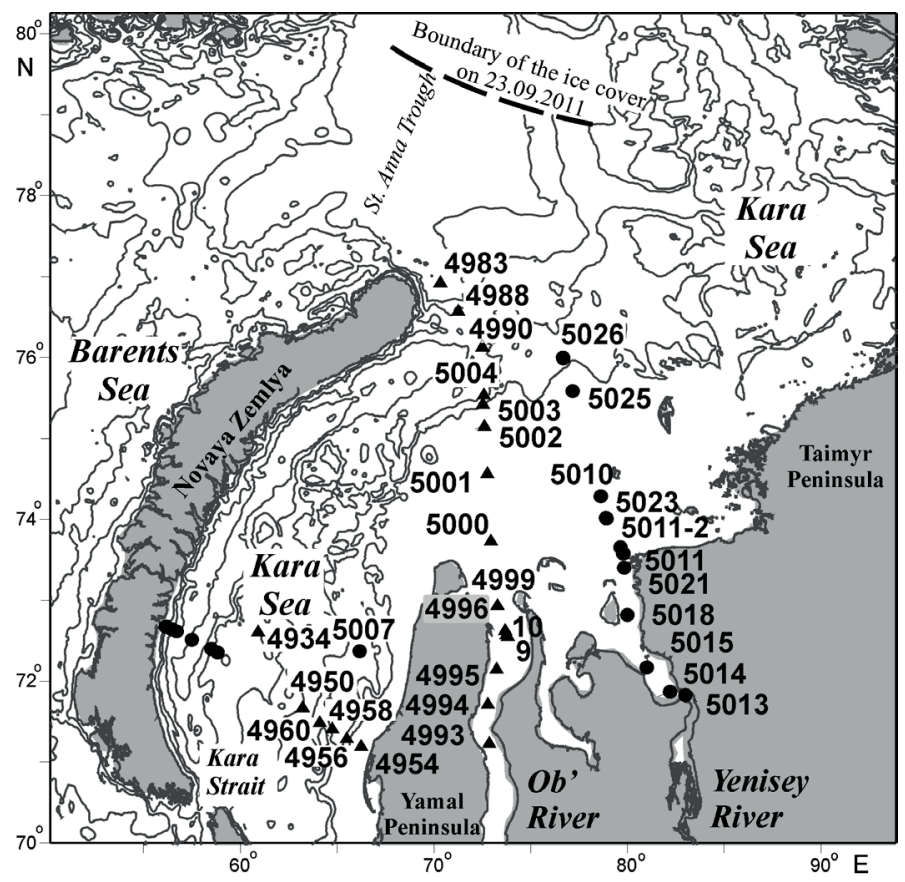

Fig. 1 The map of sampling sites during cruises of the RV Akademik Mstislav Keldysh in the Kara Sea, September-October 2007 (triangles) and 2011 (circles). Based on GEBCO bathymetry.

Data of the MODIS-Aqua ocean colour scanner (spectral channels 531 and $551 \mathrm{~nm}$ ) were used to analyse the spatial distribution of SPM concentrations (http://oceancolor.gsfc.nasa.gov/). Data calculated by standard algorithms are available at http://oceancolor.gsfc.nasa.gov/. A previous attempt to apply these algorithms for the Kara Sea has shown that the calculated and measured values differ significantly due to the physical geographic features of the Arctic seas (Kopelevich et al. 2004). To make an adequate estimate of SPM concentration based on the satellite data, a regional calculation algorithm is necessary; this was implemented after the thorough selection of representative data during our work in the Kara Sea. Our method has been applied successfully by the authors to develop regional algorithms for the White, Barents and Laptev seas (available from http://optics.ocean.ru). As a result of analysis of combined field and satellite data, the following expressions were obtained for the Kara Sea (Burenkov et al. 2010, Kuznetsova et al. 2013):

(1) $S P M=450 b_{b p}{ }^{0.98}$ for large values of SPM concentration, number of combined measurements of $b_{b p}$ (particle backscattering coefficient, $\mathrm{m}^{-1}$ ) and SPM was 34 in 2007, $r^{2}=0.87$. 
(2) $S P M=440 b_{b p}$ for large values $(>4 \mathrm{mg} / \mathrm{L}$ ) of SPM concentration, number of combined measurements of $b_{b p}$ and SPM was 22 in $2011, r^{2}=0.69$. This equation is close to the first one derived in 2007.

(3) $S P M=99 b_{b p}$ for small values $(<4 \mathrm{mg} / \mathrm{L})$ of SPM concentration, number of combined measurements of $b_{b p}$ and SPM was 162 in 2011, $r^{2}=0.55$. This equation was used for the satellite images construction (Fig. 2).

\section{RESULTS AND DISCUSSION}

\section{Distribution of SPM concentration}

The most turbid waters are in the Ob' and Yenisei Bay, the Baidaratskaya Bay, and the adjacent regions $(\geq 10 \mathrm{mg} / \mathrm{L})$ (Fig. 2). It is easy to see that frontal zones occur at the marine boundary of the $\mathrm{Ob}$ ' and Yenisei estuaries, where SPM concentration falls sharply, by an order of magnitude and more. At this hydrological front, the offshore velocity of the river waters flow decelerates and the main part of SPM sinks down to the bottom (first the coarse particles of the sand-silt fractions). Beyond this front, the transformed river waters spread in the surface layer above the more weighty marine waters. The partly transformed riverine SPM penetrates into the open sea areas, which results in relatively high SPM concentration, close to $0.5 \mathrm{mg} / \mathrm{L}$. These lenses of desalinated waters at the sea surface are typical for the Arctic seas (Lisitsyn 1995, Vasilkov et al.1999).

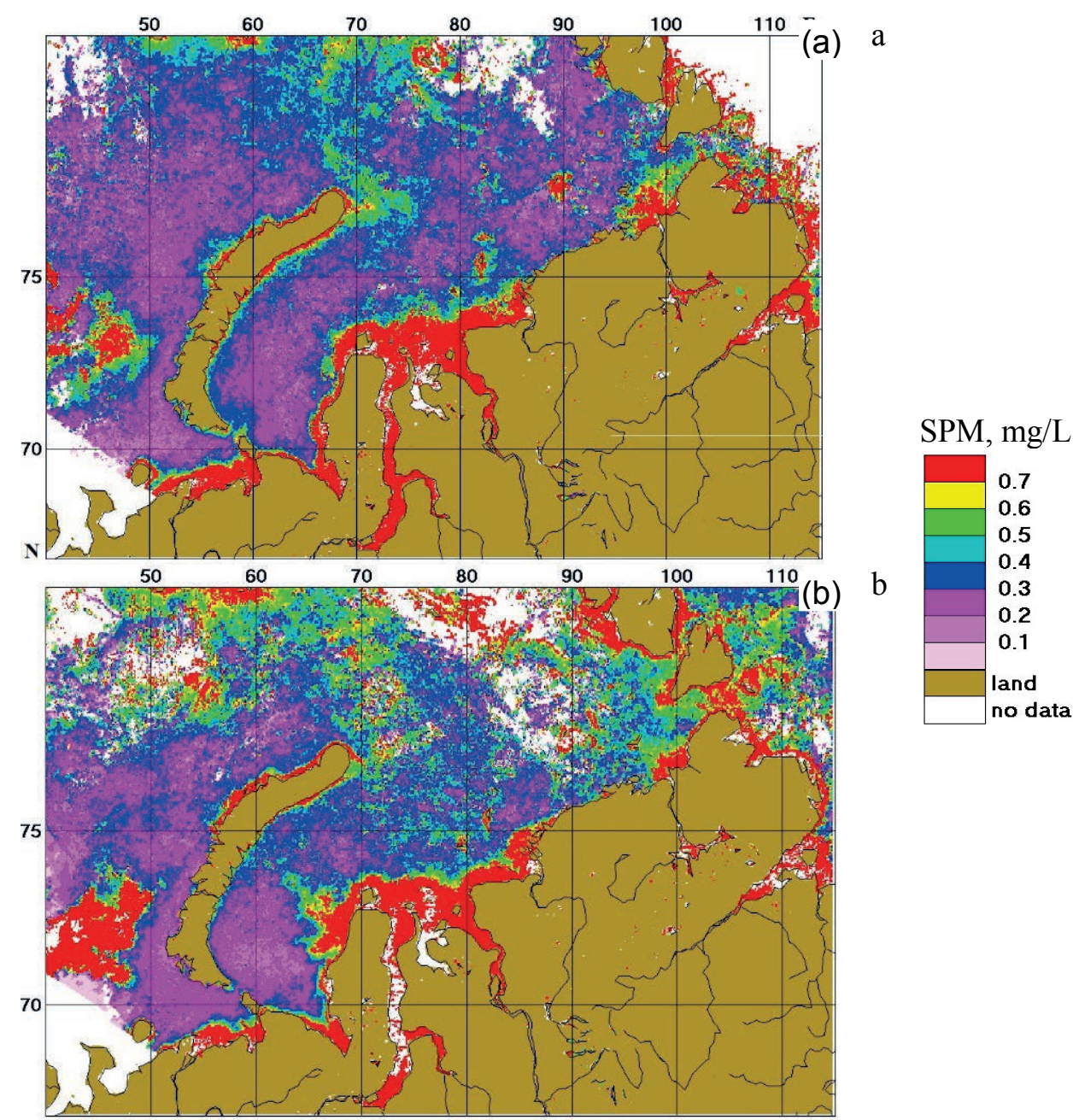

Fig. 2 Satellite images of sea surface monthly average SPM distribution for the Kara Sea (derived from MODIS-Aqua data). Images are composites over September 01-30, 2007 (a) and 01-30, 2011 (b), provided by IO RAS Ocean Optic Laboratory, http://optics.ocean.ru (Kuznetsova et al.2013). 
The average concentration of the SPM in the freshwaters of the Yenisei River estuary was eight times lower than the SPM concentration found in the estuary of the Ob' River. In the surface layer, an inverse relationship between salinity and SPM concentration and pelitic fraction content was revealed. The Kara Sea is characterized by a widespread nepheloid layer (up to $80 \mathrm{mg} / \mathrm{L}$ in the Ob' estuary) (Fig. 3). In the Ob' and Yenisei estuaries, the SPM concentration usually increases down the water column at the sites subjected to the strong influence of the river waters and remains practically unchanged at the seaward sites.

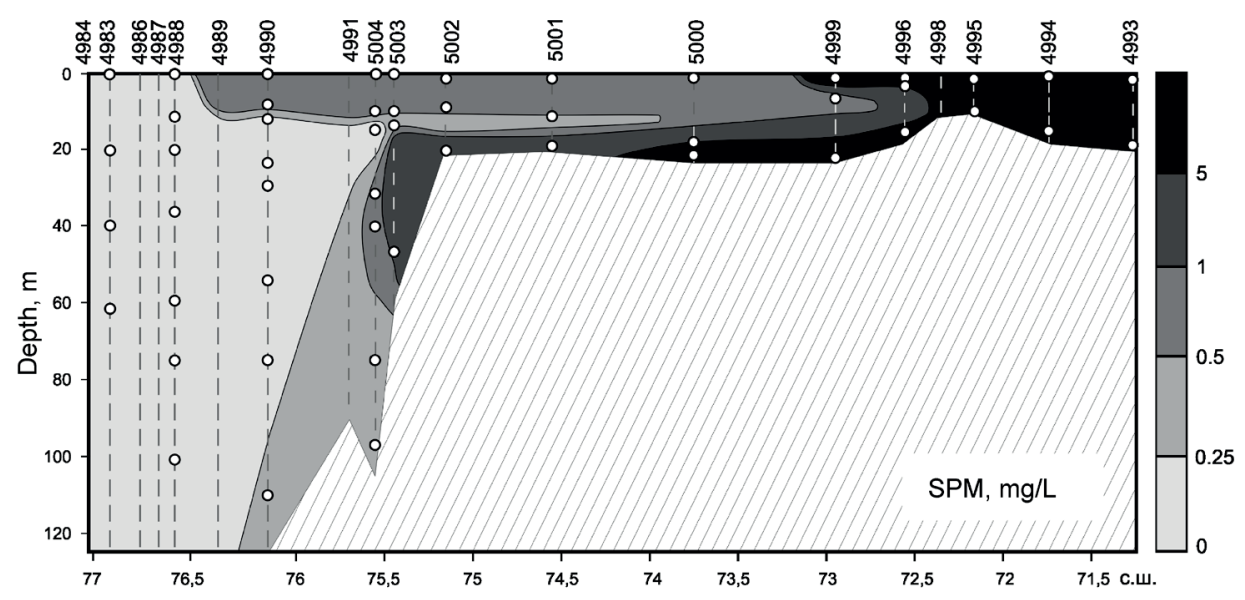

Fig. 3 Distribution of SPM concentration across the shelf along the Ob' River-St. Anna Trough transect in September 2007 (Burenkov et al. 2010), courtesy Pleiades Publishing, Inc. The circles mark the depth of water sampling. For site locations see Fig. 1.

The lowest SPM concentrations were found in the central and western Kara Sea $(0.2-$ $0.5 \mathrm{mg} / \mathrm{L}$ ). A narrow strip of turbid waters is observable close to the western margin of the Yamal Peninsula. The strip is due to coast abrasion, the re-suspension of the bottom sediments by the tidal motion, and, probably, due to water transport from Baidaratskaya Bay. The waters from the Ob' and Yenisei estuaries, whose enhanced turbidity is attributable to river runoff, propagate mainly eastwards. Adjacent to the northeastern coastal zone of the Novaya Zemlya Archipelago, SPM concentration reached $\sim 1 \mathrm{mg} / \mathrm{L}$. Apparently this is due to local upwelling (Zatsepin et al. 2010). Along the coast of the Novaya Zemlya Archipelago higher SPM concentration (1-2 mg/L) is related to the supply of extra suspended particles with the runoff of meltwater from the land.

\section{Grain size of SPM}

The SPM of the Kara Sea is an in-equigranular and heterogeneous material, but its grain size differentiation is far from random. The major part of terrigenous SPM, supplied from coastal abrasion and with river inflow, is represented by the pelitic fraction $(2-10 \mu \mathrm{m}$ in diameter) that usually constitutes about $60-90 \%$ of total SPM. The main part of the coarse terrigenous material (sandy and silty fractions) accumulates in the shallow tidal zone, in the zone of alongshore currents (about $20 \mathrm{~km}$ wide) and in the river mouth. As the distance from the river's mouth increased, water transparency also increased, and the share of mineral particles decreased notably. Simultaneously, phytoplankton particles prevailed. In the SPM the grain-size spectrum shows an increasing content of fine and coarse silt fractions, up to $80 \%$ (mostly diatoms).

The grain size may be a sensitive indicator of SPM transformation at the BBL. According to the grain-size data, the average size of the particulates in the water layer very close to the bottom (5-50 $\mathrm{cm}$ above the bottom) is $8.1 \mu \mathrm{m}$ and the pelitic fraction varies from 60 to $97 \%$. The grainsize composition of the fluffy layer may strongly differ from the size of the particulates in the near-bottom layer (1-2 $\mathrm{m}$ and 5-50 $\mathrm{cm}$ above the bottom). The content of the pelitic fraction in the fluffy layer varies from 38 to $75 \%$. All the different distributions of the fluffy layer grain-size composition are characterized by the absence of particle sorting and an expressed size extreme. 
The median diameter of the fluffy layer varies from 7 to $13 \mu \mathrm{m}$. The dispersed system of the fluffy layer is aggregately unstable. We may suggest that the coarsening of the particulates that compose the fluffy layer is related not only to the physico-chemical processes, but also to the formation of organo-mineral aggregates at the expense of the $\mathrm{C}_{\text {org }}$ increase, including the biomass of bacteria, in the fluffy layer as compared to the particles in the near-bottom water.

The low average content of pelitic particles (53.7-63.6\%) at the outer shelf may be related to the lower content of $\mathrm{C}_{\mathrm{org}}$ relative to the sites at the river's estuary.

\section{Total number of bacterioplankton (TNB)}

TNB strongly varies in different parts of the Kara Sea (Savvichev et al. 2010). In the Ob' estuary TNB reduced from $3000 \times 10^{3}$ cells $/ \mathrm{ml}$ in freshwater to $700 \times 10^{3}$ cells $/ \mathrm{ml}$ in the mixing area of fresh and salt water. In the Yenisei estuary - from $1800 \times 10^{3}$ cells $/ \mathrm{ml}$ to $230 \times 10^{3}$ cells $/ \mathrm{ml}$, respectively. TNB in the water column decreased from the south, northward across the shelf.

In the mixing area of river-sea water (salinity above $15 \mathrm{psu}$, Yenisei estuary) the TNB increases in the BBL relative to other parts of the water column. In the suprabottom layer, TNB doubled (to $1000 \times 10^{3}$ cells $/ \mathrm{ml}$ ). An especially noticeable growth of this value is observed in the fluffy layer $-17700 \times 10^{3}$ cells $/ \mathrm{cm}^{3}$ (from site 5026 northward), which implies about 30 times increase as compared to the surface layer of the water column. This is accompanied by an increase in the biomass of the heterotrophic and chemoautotrophic microorganisms, i.e. the newly formed $\mathrm{C}_{\text {org }}$, in BBL.

\section{The concentration of $P O C$}

The concentration of POC in the surface layer decreases from 1400 and $407 \mu \mathrm{g} / \mathrm{L}$ at the river estuaries to 110 and $66 \mu \mathrm{g} / \mathrm{L}$ at shelf sites along transects from the Ob' and Yenisei rivers, respectively. In contrast, the share of $\mathrm{C}_{\text {org }}$ in the SPM increases from the mouth to the shelf, which may be related both to the elevated precipitation of the suspended mineral component at the riversea barrier zone and the enrichment of the SPM in the newly formed autochthonous organic matter $(\mathrm{OM})$.

\section{The isotopic composition of POC}

The isotopic composition of POC is also related to the SPM concentration. The maximal concentrations of the latter were determined in the river's mouth, where the $\mathrm{C}_{\text {org }}$ is mainly terrigenous, and in the surface layer of the water column which is depleted in $\delta^{13} \mathrm{C}$ down to $-30.05 \%$ o (water salinity $0.05 \mathrm{psu}$ ). In the water column of the outer shelf (sites 4983 in 2007 and 5025 in 2011), the POC contains not only terrigenous but also marine OM (phytoplanktonogenic), which shifts the $\delta^{13} \mathrm{C}_{\mathrm{POC}}$ to higher values ( -23 to $-24 \%$ at water salinity $34.7 \mathrm{psu}$ ) (Savvichev et al. 2010, Lein et al. 2013).

On the transect from Yamal Peninsula (including site 4956 located 19 miles from the abrasion coast, but not influenced by river runoff) the $\delta^{13} \mathrm{C}_{\mathrm{POC}}$ reached -25.85 to $-27.54 \%$ in the surface layer on account of marine phytoplankton (Savvichev et al.2010).

The tendency known since 1993 was observed in our expeditions of 2007 and 2011: the POC of the surface layer of the water in the Kara Sea along the river-sea transect shows a shift to heavier isotopic composition (Kodina 2002, Galimov et al. 2006, Nagel et al. 2009). The runoff of freshwater was recognized up to at least $76^{\circ} \mathrm{N}$ on the basis of the isotope data in September 2011 (Lein et al. 2013).

Vertically in the water column (from top to bottom), from the water-atmosphere interface to the BBL, the POC is gradually enriched in heavy isotopes, which is especially noticeable from the value of $\delta^{13} \mathrm{C}_{\mathrm{POC}}$ in the fluffy layer (by $1-3 \%$ and more). This phenomenon was noted for the first time in August-September 1993 (Lein et al. 1996) and considered in more detail by Ivanov et al. (2010) and Lein et al. (2011).

It was concluded in the cited works, on the basis of the microbiological, radio and stable isotope data, that the microbial community of the heterotrophic and chemoautotrophic micro- 
organisms with biomass isotopically heavier than that of the POC $\left(\delta^{13} \mathrm{C}=-20 \%\right)$ is developed at the BBL in the fluffy layer owing to the supply of phytoplanktonogenic OM from above and reduced compounds from below (Ivanov et al. 2010). The abundant development of microorganisms in the fluffy layer follows from the microbiological studies, which confirm the large values of the integral rate of the dark $\mathrm{CO}_{2}$ assimilation (Lein et al. 2013).

\section{CONCLUSIONS}

The most turbid waters occur first of all in the Ob' estuary and adjacent area, as well as in the Yenisei estuary, Baidaratskaya Bay, and the adjacent regions close to Yamal Peninsula. Most of the abrasion material is usually trapped in a coastal zone up to $20 \mathrm{~km}$ wide. The lowest SPM concentrations were found in the central and western part of the Kara Sea. The waters from the $\mathrm{Ob}$ ' and Yenisei estuaries, whose enhanced turbidity is attributable to the river runoff, propagate mainly eastwards. The eastern coastal zone of the Novaya Zemlya Archipelago features a narrow strip of higher SPM concentration related to the supply of extra SPM with the meltwater runoff from the land. The nepheloid layers are widespread in the Kara Sea.

The rivers runoff of freshwater enriched by terrigenous SPM was recognized up to at least $76^{\circ} \mathrm{N}$ on the basis of the isotope data in 2011 and, according to SPM concentrations, up to at least $76.5^{\circ} \mathrm{N}$ in 2007 (up to $>1 \mathrm{mg} / \mathrm{L}$ at the inner shelf).

The fluffy layer from 0.5 to 1 up to $5 \mathrm{~cm}$ thick usually exists at the BBL. The maximal values of the TNB (up to $17.7 \times 10^{6}$ cells $/ \mathrm{ml}$ ) are observed in this layer. The maximal TNB is usually observed in the fluffy layer, where its isotopically heavy (from -18 to $-20 \%$ ) composition results in the enrichment of the isotopic composition of the total $\mathrm{C}_{\text {org }}$ in ${ }^{13} \mathrm{C}$ compared with the $\mathrm{C}_{\text {org }}$ from the water column and the sediments. The change in the isotopic composition of the $\mathrm{C}_{\text {org }}$ in the fluffy layer relative to the $\mathrm{C}_{\text {org }}$ in the SPM of the water column presumably represents a widespread phenomena supporting the leading role of microorganisms in the transformation of SPM composition at the BBL in the Arctic shelf seas.

Acknowledgements The authors are grateful to M.V. Flint for organizing the expeditions and support during the fieldwork, O.V. Kopelevich, A.S. Savvichev, E.E. Zakharova, N.A. Belyaev and M.S. Ponyaev for help in sampling and data processing. This study was supported by the Russian Foundation for Basic Research (project no. 12-05-00210-a), the Program of Basic Studies of the Presidium of the Russian Academy of Sciences (no. 23, paragraph 10.1) and President Grant no. NSh-2493.2014.5 for Leading Schools.

\section{REFERENCES}

Benson, J.D., et al. (2005) Mercury free operation of the Coulter Counter Multisizer II sampling stand. Cryobiology 51(3), 344-347.

Burenkov, V.I., Goldin, Yu.A. and Kravchishina, M.D. (2010) The distribution of the suspended matter concentration in the Kara Sea in September 2007 based on ship and satellite data Oceanology 50(5), 799-806.

Cutter, G., et al.(2010) Sampling and sample-handling protocols for GEOTRACES cruises. Version 1.0. 144. Available from: http://www.geotraces.org/libraries/documents/Intercalibration/Cookbook.pdf

Flint, M.V. (2010) 54th cruise of research vessel Akademik Mstislav Keldysh in the Kara Sea. Oceanology 50(5), 637-642.

Galimov, E.M., et al. (2006) Biogeochemistry of the Russian Arctic. Kara Sea: research results under the SIRRO Project, 19952003. Geochemistry Int. 44(11), 1053-1104.

Gebhardt, A.C. (2004) Modern sedimentation processes in the Kara Sea (Siberia). Ber. Polarforsch. Meeresforsch $490,98$.

Ivanov, M.V., Savvichev, A.S. and Lein A.Yu. (2010) Effect of phytoplankton and microorganisms on the isotopic composition of organic carbon in the Russian Arctic seas. Microbiology 79(5), 567-582.

Kodina, L.A. (2002) Carbon isotope composition of phytoplankton in the Yenisei river estuary - open sea system and the application of isotopic approach for evaluation of phytoplankton contribution to the Yenisei POC load. Reports on Polar and Marine Research 419, 143-150.

Kopelevich, O.V., et al. (2004) Application of SeaWiFS data for studying variability of bio-optical characteristics in the Barents, Black and Caspian seas. Deep-Sea ResearchII 51, 1063-1091.

Kuznetsova, O.A., et al. (2013) Development of the regional algorithm for assessment of suspended matter concentration in the Kara Sea from satellite ocean color data. In: Current problems in optics of natural waters (ONW'2013). Proceedings of VII Int. Conference, 177-181. St.-Petersburg: Nauka.

Lein, A.Yu., et al. (1996) Biogeochemical processes of the sulfur and carbon cycles in the Kara Sea Geochem. Int. 34(11), 925-941. 
Lein, A.Yu., et al. (2011) Isotopic markers of organic matter transformation at the water-sediment geochemical boundary. Doklady Earth Sci. 436(1), 83-87.

Lein, A.Yu., et al. (2013) Transformation of suspended particulate matter into sediment in the Kara Sea in September of 2011. Oceanology 53(5), 570-606.

Lisitsyn, A.P., Shevchenko, V.P. and Burenkov, V.I. (2000) Hydrooptics and particulate matter in Arctic Seas Atmospheric and Oceanic Optics 1, 61-71.

Lisitsyn, A.P. (1995) The marginal filter of the ocean. Oceanology 34, 583-590.

Lukashin, V.N., Ljutsarev, S.V. and Krasnyuk, A.D. (1999) Suspended particulate matter in the Ob and Yenisei estuaries Ber. Polarforsch 300, 155-178.

Nagel, B., et al. (2009) Stable carbon and nitrogen isotopes as indicators for organic matter sources in the Kara Sea. Marine Geology 266, 42-51.

Nöthig, E.-M., et al. (2003) Phytoplankton distribution in the inner Kara Sea: a comparison of three summer investigations. In: Siberian River Run-Off in the Kara Sea: Characterisation, Quantification, Variability and Environmental Significance (ed. by R. Stein, K. Fahl, D.K. Fütterer, E.M. Galimov and O.V. Stepanets). Proceedings in Marine Science 6, 163-183. Amsterdam: Elsevier.

Platonov, N.G., Mordvintsev, I.N. and Rozhnov, V.V. (2012) Analysis of the Arctic Sea ice conditions for 2011 at the onset of summer minimum.Izvestiya. Atmospheric and Oceanic Physics 48(9), 1027-1038.

Savvichev, A.S., et al. (2010) Microbial processes of the carbon and sulfur cycles in the Kara Sea.Oceanology 50(6), 893-908.

Stein, R. and Fahl., K. (2004) The Kara Sea: distribution, sources, variability and burial of organic carbon. In: The organic carbon cycle in the Arctic Ocean (ed. by R. Stein and R.W. Macdonald), 237-266. Berlin Heidelberg: Springer Verlag.

Stein, R. (2000) Circum Arctic river discharge and its geological record. Int. J. of Earth Sci. 89, 447-449.

Vasiliev, A., et al. (2005). Permafrost and coastal dynamics at the Barents and Kara Sea key sites. Geo-Marine Letters 25(22-23), 110-120.

Vasilkov, A.P., Ruddick, K.G. and Burenkov, V.I. (1999) The spectral reflectance and transparency of river plume waters. Int J. Remote Sens. 20(13), 2497-2508.

Vinogradov, M.E., Shushkina, E. A. and Lebedeva, L.P. (1994) Mesoplankton of the eastern part of the Kara Sea and estuaries of the $\mathrm{Ob}$ and Yenisei Rivers. Oceanology 34(5), 716-723.

Zatsepin, A.G., et al. (2010) Circulation in the south-western part of the Kara Sea in September 2007. Oceanology 50(5), 643-656. 